\title{
Research on the Mode of College Students' Network Political Participation
}

\author{
Ge Jia Jia ${ }^{1}$ \\ ${ }^{\text {IS }}$ chool Of European Studies, Tianjin Foreign Studies University, NO.117 Ma Chang Road, Tianjin \\ 300204,China.Emali:gejiajia0619@163.com.
}

\begin{abstract}
With the rapid development of new media technology in China, the mode of network political participation has become an significant way for college students to participate in the Internet era, which affects their awareness, enthusiasm and way of participation in politics. The purpose of this paper is to study the mode of College Students' network political participation from macro and micro levels.
\end{abstract}

Keywords: college students, political participation, new media age

\section{THE CONCEPT OF NETWORK POLITICAL PARTICIPATION}

The network political participation is different from the traditional political participation mode in the past. It takes the new media technology as the carrier, also it has the equality, the concealment, the discreteness, the interaction and the convenience. It has the obvious difference with the traditional political participation behavior, which is one kind of subversion to the traditional mode. As a new type of political participation mode, network political participation has many forms, including political communication, political catharsis, election and association, etc. However the network political participation mode relies on the latest network technology platform, the traditional form of political participation will also be in the original. There are some new changes on the basis of them.

The concept of network political participation can be understood in both broad and narrow senses. In a broad sense, network political participation is a kind of behavior that takes the network as the carrier and participates in political activities involving state power and specific interests. In a narrow sense, it can be defined as a series of specific political behaviors, such as taking the network as the carrier, taking ordinary citizens as the main body, taking part in government decision-making and social management as the purpose, using the Internet to carry out network election, network dialogue and discussion. This paper mainly discusses the network political participation in a narrow sense. In a certain sense, network political participation originates from the real society and is closely related to the political life of the real society. It is an objective mapping of political participation behavior on the network platform in the real society.

\section{THE CURRENT SITUATION AND IMPORTANCE OF COLLEGE STUDENTS' NETWORK POLITICAL PARTICIPATION}

Now China is heading for a new journey, and socialism with Chinese characteristics has entered a new era. Xi Jinping's new socialist thought with Chinese characteristics has become the guide of action for the whole Party and the whole nation to realize the great rejuvenation of China. Contemporary college students, as the future successors of the socialist cause that the party and the state focus on, have a strong sense and desire of political participation. With the continuous development of new media technology in China, there are more and more college students have fast and convenient media carriers to participate in network life, particularly network political participation. Especially college students, growing up in the Internet era, with the improvement of China's comprehensive national strength and the continuous development of opening up, have characteristics of high enthusiasm and attention to political events. This series of development has promoted the rapid development of College Students' network political participation.

Network political participation is different from the traditional way of political participation. It makes college students' network political participation more and more convenient depending on the advantage, the virtual and convenient nature of the network, and it is low-cost and anonymous. It omits the tedious steps and layers of approval procedures required by the traditional sense of political participation, and to a certain extent, it releases more enthusiasm and space for college students to participate in politics. At the same time, a variety of media carriers also provide plenty of alternative channels for college students' online political participation. Through network political participation, college students can take the initiative to participate in the major issues of national society, further strengthen their feelings of home and country,their concerns for society, and express their opinions through rational 
channels, which is also conducive to the political stability.

\section{ON THE PATH OF COLLEGE STUDENTS' NETWORK POLITICAL PARTICIPATION}

With the development and maturity of new media technology, the global network has nothing to do with each other. The future trend of network development will surely include every global citizen in the Internet. Network political participation will have a huge impact on China's future social and political life. It may not only be a good buffer for political conflicts, a driving force for democratic development, but also be out of control, a catalyst for political conflicts, and a political order that threatens the future social stability. Because of the two-way interaction of network political participation, only the unilateral system norms and development of the government are not enough to promote the benign development of the two-way interaction mechanism of network political participation. Therefore, how to guide and regulate college students' network political participation requires efforts from both macro and micro levels.

\subsection{Macro Level}

As the government holds most of the information of social economy and culture, it plays an important role in the network political participation. Therefore, the development of network political participation requires the government to vigorously develop new media technology, actively create targeted laws and regulations of network political participation, standardize the order of network political participation, and maintain the privacy security of network users. At the same time, the government should also vigorously improve the e-government, closely combine online politics with offline implementation, and avoid the mere formality of online participation.

\subsubsection{Improve the construction of E-government}

The development of new media technology is an unprecedented innovation for the traditional mode of political participation. It not only affects the ordinary people but also the government. It makes the government join the ranks of digitalization. E-government and e-government came into being. Governments at all levels hold more than $80 \%$ of all kinds of social, economic and cultural information. Only when the government fully builds and manages the e-government platform, timely publishes the government information, and maintains it by specially assigned personnel, can the public understand and grasp the correct policy, law and other information in the massive information network, and can the rational political participation activities be carried out on this basis. Egovernment platform has become an important basis for online political participation. By querying relevant information in various e-government platforms established by the government, people make value judgments based on the information they have acquired, and then transmit their personal interest demands to the government through the eplatform, thus affecting the government's decision-making, and completing the operation of the political system conveniently and quickly Cheng.

\subsubsection{Two way interaction between "online politics" and "offline practice"}

The extensive network is becoming a new and more effective participation carrier. The mode of network political participation should not only rely on the virtual participation of network means, but also extend the online participation to the offline, and integrate the online participation and offline practice.

In the investigation of College Students' degree and cognition of network political participation after the new media age, the author found that the behavior of network political participation is related to their degree of political participation in real life. Therefore, the author designed two different forms to test the correlation among the online political participation, offline political participation and the degree of concern. The two forms are composed of five variables respectively.

By analyzing the interaction between them and observing the gamma value, it is found that the gamma value is 0.393 , which has a certain correlation, and the sig value is equal to 0.000 , which has a good inferential value.

\section{Symmetric Measures}

\begin{tabular}{|c|c|c|c|c|}
\hline & Value & Asymp. Std. Error $^{\mathbf{a}}$ & Approx. $^{\mathbf{b}}$ & Approx. Sig. \\
\hline $\begin{array}{c}\text { Ordinal by Ordinal Gamma } \\
\text { N of Valid Cases }\end{array}$ & 0.393 & 0.076 & 5.139 & 0.000 \\
83 & & & \\
\hline
\end{tabular}

a. Not assuming the null hypothesis.

b. Using the asymptotic standard error assuming the null hypothesis.

It can be concluded that college students' political participation on the Internet is closely related to their attention to political affairs in real life. In fact, the behavior in the network virtual platform is also an objective mapping of College Students' participation in politics in real life. The essence of College Students' network political participation is to participate in social management and influence the formulation of public policies, so as to put 
forward their own views and opinions on social and political life. The government should pay attention to the expression of public opinions and actively respond, and build a participatory and responsive government. Only by building a standardized and comprehensive mechanism of opinion expression and feedback, can we meet the growing willingness of college students to participate in politics, and can we keep citizens' political participation within a reasonable and legal range.

\subsubsection{Improve the construction of laws and regulations}

As the saying goes, "no rules, no circles.". If the first mock exam mode is to be developed in the future, we must standardize it legally to make it institutionalized and normalized. As a rigid mechanism to regulate the form of network political participation, network legislation is also the most critical step.

Although many laws and regulations of our country involve the relevant aspects of the network political participation, they are usually rough lines. We should take this as the backbone, combine with the introduction of other relevant laws, administrative regulations, departmental regulations and local regulations, and build an integrated, systematic and coordinated network legal system with professional laws as the main line and other laws and regulations as the auxiliary, so as to ensure the healthy development of network political participation and create conditions for promoting the development of democratic politics.

\subsection{Micro Level}

As the main body of the new-type network political participation, the cultural quality, democratic consciousness and political participation ability of the college students themselves also affect the development of the network political participation model. Therefore, from the perspectives of college students themselves, the following aspects should be focused on in the future.

\subsubsection{Improve the network literacy of College Students}

In the process of political participation on the Internet, college students have not fully understood the concept of politics, and their knowledge reserve is not enough, which directly affects the purpose, mode, nature and influence of their own political participation. Therefore, on the one hand, colleges and universities should pay attention to cultivating the correct world outlook and values of college students, and establish the correct concept of network political participation, guiding them to correctly understand and the meaning of political affairs, enhancing their sense of political efficacy and shaping their sense of political obligation. At the same time of cultivating citizen culture, we should also strengthen the cultivation of the ability of participating in politics on the Internet, improve the ability of distinguishing and analyzing the Internet information of college students, enable them to collect the information they need flexibly and freely, and make correct value judgment on the information. Pay attention to the study of the way and characteristics of the psychological activities of college students in the process of network political participation, and put forward corresponding policy suggestions through rational analysis and discussion.

\subsubsection{Strengthen the construction of ethics and morality of network political participation}

Since college students are still in a critical period of growing up, the knowledge system is imperfect, the emotional awareness is immature, and the world outlook and values are still forming, some college students' self-awareness of political participation after 00 is not clear, they can not correctly and reasonably express their personal interests through the network, and they will be easily misled by the false information or network rumors in the network. On the other hand, due to the anonymity and disorder of the network, some netizens tend to participate in politics irrationally and emotionally. They are easy to express improper opinions on some social hot issues and sensitive topics without any scruples, even to express their emotions as quickly as they can, create false information, distort objective facts, attack the parties of news events arbitrarily, etc. Therefore, while promoting the construction of new media, we should also pay attention to actively guide the rational participation of college students in politics. We should strengthen the construction of College Students' network morality and guide them to access the Internet in a civilized way through publicity and education. At the same time, we should publicize the network knowledge, strengthen the network training, and improve the information identification ability of network college students, so that they can distinguish right from wrong and not be confused by the false information of the network. The government should also make clear the responsibilities and obligations of netizens, establish a reasonable civilized network convention, restrict and guide the behaviors of netizens, and help to realize the benign interaction between the government and netizens while ensuring the netizens to reasonably express their interest demands and participate in social and political life.

\section{CONCLUSION}

At present, with the development of network technology, the enthusiasm and behavior of College Students' network participation in politics are increasing day by day. However, there are also various problems in the process of College Students' online political participation, facing the development dilemma. In view of the current difficulties, the improvement and development of College Students' 


\section{REFERENCES}

network political participation mode requires us to start from macro and micro aspects: first, from the macro level, we should focus on the development of new media technology, improve the construction of e-government; do a good job in the two-way interaction of "online politics" and "offline practice"; improve the construction of laws and regulations. Secondly, from the micro level, we should improve the network literacy of college students, cultivate the public spirit, and strengthen the ethical and moral construction of network political participation. The new era needs a new mode of participation. Only in this way can technology truly serve the people and promote the healthy development of our social and political life.

\section{ACKNOWLEDGMENT}

This work was supported by Humanities and social sciences of the Ministry of education (19JDSZ3009) and Tianjin University Humanities and social sciences research project (2018SK072).
[1] Fan Jinshan. Network politics and its development trend [J]. Cutting edge, 2010 (17)

[2] Guo Furong. On the rise of Internet politics and its rational limits [J]. China Youth Research, 2010 (9)

[3] (USA) mark Sloka. The great conflict: the threat of cyberspace and high technology to reality [M]. Jiangxi education press, 1999

[4] (plus) Marshall markluhan. Extension of human beings - General Theory of media [M]. Chengdu: Sichuan people's publishing house, 1992

[5] Li Weining. China begins to enter the "new normal" of Internet [n]. Guangming Daily, January 16, 2015 (5)

[6] Li Jidong. To construct a new pattern of public opinion guidance, we need to pay attention to the pertinence of micro discourse [J]. Hongqi manuscript, 2016 (23): 27-29 